\title{
GENETIC CONTROL OF COWPEA SEED SIZES
}

\author{
Francisco Cláudio da Conceição Lopes ${ }^{1,4}$; Regina Lúcia Ferreira Gomes ${ }^{2 *}$; Francisco Rodrigues \\ Freire Filho ${ }^{3}$ \\ ${ }^{l}$ USP/ESALQ - Depto. de Genética, C.P. 83 - 13400-970 - Piracicaba, SP - Brasil. \\ ${ }^{2}$ UFPI - Depto. de Fitotecnia, Campus Universitário Petrônio Portela, s/n, Ininga - 64049-550 - Teresina, PI - Brasil. \\ ${ }^{3}$ Embrapa Meio-Norte, C.P. 01 - 64006-221 - Teresina, PI - Brasil. \\ ${ }^{4}$ FAPESP scholar. \\ *Corresponding author <rlfgomes@ufpi.br>
}

\begin{abstract}
Cowpea [Vigna unguiculata (L.) Walp.] is one of the most widely adapted grain legumes in hot regions of Africa, Asia and the Americas. In the semiarid Northeast of Brazil, it is the main subsistence crop, an excellent protein source of low cost, for the poor population. The objective of this work was to estimate genetic parameters to understand the inheritance of seed sizes in cowpea. The parents $\mathrm{P}_{1}$ and $\mathrm{P}_{2}$ and the generations, $\mathrm{F}_{1}, \mathrm{~F}_{2}, \mathrm{BC}_{1}$ and $\mathrm{BC}_{2}$ of the cross TVx5058-09C X Manteiguinha formed the genetic material for this study. These six generates $\left(\mathrm{P}_{1}, \mathrm{P}_{2}, \mathrm{~F}_{1}, \mathrm{~F}_{2}, \mathrm{BC}_{1}\right.$ and $\left.\mathrm{BC}\right)$ were evaluated in a completely randomized blockdesign with six replications, in Teresina - PI, Brazil, in 1998. The genetic parameters estimated were: phenotypic and total genetic variance, additive and dominance genetic components of variance and the variance attributed to the environment, heritability in the broad and narrow senses, average degree of dominance and the number of genes controlling the character. The additive - dominance model fitted the data for 100 -seeds weight in as much as the midparental value and the additive effect were the more important genetic parameters for the determination of this character. The number of genes that control its expression is five. The occurrence of high values for narrow sense heritability indicates that the selection for seed size can be made in early generations.
\end{abstract}

Key words: Vigna unguiculata, 100-seed weight, inheritance, gene effect

\section{CONTROLE GENÉTICO DO TAMANHO DAS SEMENTES DE CAUPI}

RESUMO: Caupi [Vigna unguiculata (L.) Walp.] é uma das leguminosas mais adaptadas às regiões quentes da África, Ásia e das Américas. No semi-árido do nordeste do Brasil é a principal cultura de subsistência, por ser uma excelente fonte de proteína de baixo custo para a população mais carente. O objetivo deste trabalho foi estimar parâmetros genéticos que podem explicar a herança do tamanho das sementes de caupi. Os genótipos parentais $\mathrm{P}_{1}$ e $\mathrm{P}_{2}$ e as gerações $\mathrm{F}_{1}, \mathrm{~F}_{2}, \mathrm{RC}_{1}$ e $\mathrm{RC}_{2}$ do cruzamento TVx5058-09C X Manteiguinha, constituíram o material genético utilizado no estudo. As seis populações $\left(\mathrm{P}_{1}, \mathrm{P}_{2}, \mathrm{~F}_{1}, \mathrm{~F}_{2}, \mathrm{RC}_{1} \mathrm{e} \mathrm{RC}_{2}\right)$ foram avaliadas num experimento em blocos casualizados com seis repetições, em Teresina - PI; o plantio foi realizado em março de 1998. Os parâmetros genéticos estimados foram variâncias fenotípica, genética total, genética aditiva e dos desvios de dominância e devido aos efeitos do ambiente, herdabilidades no sentido amplo e restrito, grau médio de dominância e número dos genes que controlam o caráter. $\mathrm{O}$ modelo aditivo - dominante ajustou-se aos dados do peso de 100 sementes, visto que a média e o efeito gênico aditivo foram os parâmetros genéticos mais importantes na determinação desse caráter. O número dos genes que controlam sua expressão é cinco. A ocorrência de alto valor para a herdabilidade no sentido restrito indicou que a seleção para o tamanho da semente pode ser realizada em gerações segregantes iniciais.

Palavras-chave: Vigna unguiculata, peso de 100 sementes, herança, efeito gênico

\section{INTRODUCTION}

Cowpea is prominent among grain legumes grown in northeastern Brazil, since it is an excellent source of low-cost protein and a basic food for the poorer groups of the population. It is one of the main subsistence crops in the region, because of its good adaptability to the edaphic-climatic conditions, low soil fertility requirements and presents natural capability of fixing atmospheric nitrogen through symbiosis with bacteria of the genus Bradyrhizobium.
Seed size in cowpeas is important because it directly influences productivity and, together with color standards, determines grain quality for commercialization. The existing variation for seed size ranges between less than $10 \mathrm{~g}$ per 100 seeds and approximately $30 \mathrm{~g}$ (Ehlers \& Hall, 1997). In that respect, the consumer market in the northeast shows preference for a seed standard from medium to large (15 to $25 \mathrm{~g}$ ), with a minimum tolerance limit that varies from state to state (Araújo, 1988). It is therefore understandable that knowledge about the genetic factors responsible for the 
inheritance of this character is essential for breeding programs which present great genetic variability in germplasm collections of the species. However, information is insufficient and has produced contradictory results with regard to the type of genetic action and the number of genes that control the character. Therefore, the objective of the present work was to estimate genetic parameters that could explain heritability for seed size in cowpea.

\section{MATERIAL AND METHODS}

The two cowpea genotypes utilized in the crosses were: TVx 5058-09C $\left(\mathrm{P}_{1}\right)$ and Manteiguinha $\left(\mathrm{P}_{2}\right)$, both from at the Embrapa Meio-Norte germplasm collection, and selected because of their contrasting 100-seed mean weights, around 16 and 5 grams, respectively. Crosses were performed. In Teresina, Piauí, inside a shade house and in two stages; in the first stage the fixed generations $\mathrm{P}_{1}, \mathrm{P}_{2}$ and $\mathrm{F}_{1}\left(\mathrm{P}_{1} \mathrm{xP}_{2}\right)$ were obtained, while the segregating generations $\mathrm{F}_{2}\left(\mathrm{~F}_{1} \mathrm{xF}_{1}\right), \mathrm{BC}_{1}\left(\mathrm{P}_{1} \mathrm{xF}_{1}\right)$ and $\mathrm{BC}_{2}\left(\mathrm{P}_{2} \mathrm{xF}_{1}\right)$ were obtained in the second.

In March, 1998, the six populations were established in the field. The experimental design was set up as random blocks with six replicates. The plots consisted of a $3.0 \mathrm{~m}$ row for parents and the $\mathrm{F}_{1}$ generation, three $3.0 \mathrm{~m}$ rows for generations $\mathrm{BC} 1$ and $\mathrm{BC} 2$, and six $3.0 \mathrm{~m}$ rows for the $\mathrm{F}_{2}$ generation, with plants spaced $0.80 \mathrm{~m} \mathrm{x}$ $0.30 \mathrm{~m}$

Seed size observations were accomplished by determining the mean weight for 100 seeds, assessed in eight competitive plants from each row. The genetic studies based on means and variances, obtained from individuals in populations $\mathrm{P}_{1}, \mathrm{P}_{2}, \mathrm{~F}_{1}, \mathrm{~F}_{2}, \mathrm{BC}_{1}$ and $\mathrm{BC}_{2}$, were performed according to methodology presented in Mather \& Jinks (1984) and Cruz \& Regazzi (1994), using the GENES software (Cruz, 1997).

The parameters estimated were mean ( $\underline{\mathrm{m}})$, additive variance (a), variance due to dominance ( $\underline{\mathrm{d}})$, additive $\mathrm{x}$ additive epistatic variance (aa), additive $\mathrm{x}$ dominant epistatic variance (ad), and dominant $x$ dominant epistatic variance $(\underline{\mathrm{dd}})$. Estimates were based on population means, from the complete model, and were calculated through the weighted least squares method, since the means for the six populations were not obtained with the same precision. The variance associated to each parameter was obtained by applying the properties of the variance, under the assumption that the population means are independent. After evaluating the null hypothesis significance for each of these parameters ( $t$ test), those that were not different from zero were eliminated and then the additive-dominance simplified genetic model was utilized. Parameters $\underline{\mathrm{m}}$, a and $\underline{\mathrm{d}}$ were again estimated by the weighted least squares method and evaluated as to their significance.
The simplified model was fitted by quantifying the coefficient of determination $\left(\mathrm{R}^{2}\right)$, which compares observed means against estimated values. The sum of squares for the parameters associated to this model was decomposed into sums of squares attributed to each individual parameter, adjusted for all other effects by the Gauss Elimination Method.

The variance estimates attributed to environment, total genetic, additive and dominance deviation effects were obtained from the phenotypic variances for populations $\mathrm{P}_{1}, \mathrm{P}_{2}, \mathrm{~F}_{1}, \mathrm{~F}_{2}, \mathrm{BC}_{1}$ and $\mathrm{BC}_{2}$. These estimates allowed the determination of heritabilities in the broad and narrow sense, mean degree of dominance and minimum number of genes that control each character, by using Burton's (1951) expression.

\section{RESULTS AND DISCUSSION}

Great contrast occurred between the parental genotypes (Table 1), reducing the possibility of flaws in the estimates of parameters (Cruz \& Regazzi, 1994). The means of generations $F_{1}$ and $F_{2}$ are similar and intermediate relative to the parental mean, demonstrating that the type of allelic interaction predominant between the genes that condition variability in cowpea seed weight is additive.

Only the mean $(\mathrm{m})$ and the additive genetic effect (a) were significant by the $t$ test, $(P<0.05)$ (Table 2 ). Evaluating two crosses (Umaharan et al., 1997), adjusted the 100 -seed weight data for one of them to the additivedominance model, and to the complete model for the other.

The contribution of additive effect genes relative to dominance genes toward cowpea seed weight was expressive, characterizing an additive allelic interaction (Table 2). This result is crucial for breeding programs. When an additive allelic interaction is predominant, selection is facilitated, because superior individuals will produce superior descent. Similar results were obtained by Sène (1968), Ogunbodede \& Fatunla (1985) and Shakarad et al. (1995), for Vigna unguiculata. Rahman $\&$ Saad (2000) also found a positive and significant additive genetic effect for seed weight in four crosses of Vigna sesquipedalis.

Even though the decomposition of the sum of squares of the parameters by the Gauss Elimination Method is not orthogonal (Table 3 ), the measure denoted by $\mathrm{R}^{2}$ can be utilized to give an idea about the importance of a particular genetic effect for the available variability of the character being studied (Cruz \& Regazzi, 1994). The additive-dominance model is sufficient to explain the behavior of the mean for the generations. The genetic variability present in $\mathrm{F}_{2}$ resulted exclusively from the additive genetic effects, since the dominance deviations were null. These results confirm those presented in Table 2. 
Table 1 - Number of plants, means $(\bar{x})$, variance $\left(\sigma^{2}\right)$ and means variance $\left(V_{(\bar{x})}\right)$ for 100-seed weight in six genetic populations $\left(\mathrm{P}_{1}, \mathrm{P}_{2}, \mathrm{~F}_{1}, \mathrm{~F}_{2}, \mathrm{BC}_{1}\right.$ e $\left.\mathrm{BC}_{2}\right)$ for cowpea (Vigna unguiculata (L.) Walp.).

\begin{tabular}{lcrcc}
\hline Population & No. of plants & & $\sigma^{2}$ & $\left.\mathrm{~V}_{(}\right)$ \\
\hline $\mathrm{P}_{1}(\mathrm{TVx} 5058-09 \mathrm{C})$ & 38 & 15.14 & 2.24 & 0.06 \\
$\mathrm{P}_{2}$ (Manteiguinha) & 42 & 4.82 & 0.63 & 0.01 \\
$\mathrm{~F}_{1}$ & 44 & 10.22 & 1.68 & 0.04 \\
$\mathrm{~F}_{2}$ & 279 & 9.44 & 4.94 & 0.02 \\
$\mathrm{BC}_{1}\left(\mathrm{~F}_{1} \times \mathrm{TVx5058-09C)}\right.$ & 140 & 12.50 & 4.24 & 0.03 \\
$\mathrm{BC}_{2}\left(\mathrm{~F}_{1} \times\right.$ Manteiguinha) & 132 & 7.01 & 2.69 & 0.02 \\
\hline
\end{tabular}

Table 2 - T test of the null hypothesis significance for the genetic parameters $\mathrm{m}$, a, $\mathrm{d}$ estimated by the additive-dominance model for 100-seed weight in six genetic populations $\left(\mathrm{P}_{1}, \mathrm{P}_{2}, \mathrm{~F}_{1}, \mathrm{~F}_{2}, \mathrm{BC}_{1}\right.$ e $\left.\mathrm{BC}_{2}\right)$, for cowpea.

\begin{tabular}{lccccc}
\hline Parameter $^{1}$ & Estimate & Variance & $\mathrm{t}$ & d.f. & Significance \\
\hline $\mathrm{m}$ & 9.828 & 0.014 & $84.01^{*}$ & 626 & $P<0.05$ \\
$\mathrm{a}$ & 5.157 & 0.013 & $45.26^{*}$ & 78 & $P<0.05$ \\
$\mathrm{~d}$ & -0.085 & 0.049 & -0.38 n.s. & 669 & $P<0.80$ \\
\hline
\end{tabular}

${ }^{1} \mathrm{~m}=$ mid-parental value; $\mathrm{a}=$ additive effect; $\mathrm{d}=$ dominance effect.

$* P<0.05 ;$ n.s $=$ not significant.

The model-fitting evaluation was performed by the correlation between observed means and estimated values, by using the equation $\hat{\gamma}_{\chi}=\chi \hat{\beta}$, according to Cruz $\&$ Regazzi (1994). The additive-dominance model allows predicted means that correlate with observed means to be obtained at a $100 \%$ magnitude, which is equivalent to a $100 \%$ determination (Table 4).

The estimates of phenotypic, genotypic, additive, dominance and environment variances, of heritabilities in the broad and narrow senses, of the mean degree of dominance and the number of genes that control the 100-seed weight in cowpea were also calculated. The largest part of the observed variation is genetic in nature (3.38), with additive variance (2.96), which corresponds to $87.57 \%$, as its most important component (Table 5). Dominance variance $(0.42)$, corresponding to $12.43 \%$, was the parameter contributing the least toward phenotypic variance. It is possible to obtain superior materials by selecting from $\mathrm{F}_{2}$-derived populations, and the gain during the selection cycles could be satisfactory, since the additive-nature component shows higher magnitude (Sène, 1968; Shakarad et al., 1995). Additive variance, which depends only on the contribution from homozygotes and can be fixed by selection, is the most important component in gain prediction expressions (Ramalho et al., 1993).

Teófilo et al. (1984), whose estimates of genetic variance components were obtained according to methodology by Hayman (1954), Ogunbodede \& Fatunla (1985) and Umaharan et al. (1997), also found that the additive genetic variance was the main component of genetic variance. Biradar et al. (1994) estimated dominance components that were higher than the additive genetic variance components.

The estimated values for heritability in the broad and narrow senses were $68.46 \%$ and $59.87 \%$, respectively. This represents the percentage of total variation for
Table 3 - Analysis of variance showing that decomposition is not orthogonal of the sum of squares of the genetics parameters ( $\mathrm{m}, \mathrm{a}, \mathrm{d})$ by the Gauss Elimination Method for 100-seed weight in six genetic populations $\left(\mathrm{P}_{1}\right.$, $\mathrm{P}_{2}, \mathrm{~F}_{1}, \mathrm{~F}_{2}, \mathrm{BC}_{1}$ e $\mathrm{BC}_{2}$ ) for cowpea.

\begin{tabular}{lrr}
\hline $\begin{array}{l}\text { Sources of } \\
\text { variation }^{1}\end{array}$ & $\begin{array}{c}\text { Sums of } \\
\text { squares }\end{array}$ & $\mathrm{R}^{2}(\%)$ \\
\hline $\mathrm{m} / \mathrm{a}, \mathrm{d}$ & 7057.62 & 77.51 \\
$\mathrm{a} / \mathrm{m}, \mathrm{d}$ & 2057.62 & 22.49 \\
$\mathrm{~d} / \mathrm{m}, \mathrm{a}$ & 0.14 & 0.00 \\
\hline Total & 9106.11 & 100.00 \\
\hline
\end{tabular}

${ }^{1} \mathrm{~m}=$ mid-parental value; $\mathrm{a}=$ additive effect; $\mathrm{d}=$ dominance effect.

Table 4 - Observed means (Y obs.) and estimated means (Y est.) for 100-seed weight in six genetic populations $\left(\mathrm{P}_{1}, \mathrm{P}_{2}, \mathrm{~F}_{1}, \mathrm{~F}_{2}, \mathrm{BC}_{1}\right.$ and $\left.\mathrm{BC}_{2}\right)$ for cowpea.

\begin{tabular}{lrc}
\hline Population & Y obs. & Y est. \\
\hline $\mathrm{P}_{1}$ (TVx5058-09C) & 15.14 & 14.98 \\
$\mathrm{P}_{2}$ (Manteiguinha) & 4.82 & 4.67 \\
$\mathrm{~F}_{1}$ & 10.22 & 9.74 \\
$\mathrm{~F}_{2}$ & 9.44 & 9.79 \\
$\mathrm{BC}_{1}\left(\mathrm{~F}_{1} \times\right.$ TVx5058-09C) & 12.50 & 12.36 \\
$\mathrm{BC}_{2}\left(\mathrm{~F}_{1}\right.$ x Manteiguinha) & 7.01 & 7.21 \\
$\mathrm{r}(\mathrm{Y}$ obs., Y est.) & \multicolumn{2}{c}{1.0} \\
\hline $\mathrm{R}^{2}(\%)$ & \multicolumn{2}{c}{100.0} \\
\hline
\end{tabular}

population $\mathrm{F}_{2}$ attributed to genetic causes and to additivenature genetic causes. Therefore, if the environment influence is smaller than the genetic influence on the total variation of the 100 -seed weight, the possibility of obtaining a satisfactory selection gain becomes evident. The estimated coefficients of heritability are within the limits found in the literature (Aryeetey \& Laing, 1973; Bordia et al., 1973; Kheradnam \& Niknejad, 1974; Bhowal, 1976; Drabo et al., 1984; 1985; Teófilo et al., 1984; Biradar et al., 1993; Sawant, 1994; Rocha et al., 1995; Umaharan et al., 1997; Lopes et al., 2001). 
Table 5 - Estimates of phenotypic, genotypic, additive, dominance and environment variances, heritabilities in the broad and narrow senses, average degree of dominance and the number of genes that control the 100 -seed weight for cowpea.

\begin{tabular}{lc}
\hline Parameter & Estimate \\
\hline Phenotypic variance & 4.94 \\
Genotypic variance & 3.38 \\
Additive variance & 2.96 \\
Dominant variance & 0.42 \\
Environment variance & 1.56 \\
Broad sense heritability $(\%)$ & 68.46 \\
Narrow sense heritability $(\%)$ & 59.87 \\
Average degree of dominance & 0.54 \\
Number of genes & 5 \\
\hline
\end{tabular}

The mean degree of dominance (0.54) demonstrates the partial dominance of large seeds over small; $\mathrm{F}_{2}$ generation individuals lean toward larger-seed parents. The occurrence of partial dominance for this character was also observed by Teófilo et al. (1984) and Umaharan et al. (1997). The positive sign of the estimate indicates that the dominance deviations provided by the intra-allelic interactions between the genes that control the character are possibly unidirectional, i.e., the sum of deviations leans toward the phenotypic manifestation represented by larger seeds. Similar results were found by Biradar et al. (1993) and Sawant (1994). Aryeetey \& Laing (1973) and Bhowal (1976) observed dominance of small seeds over large ones.

The value for the mean degree of dominance shows that the character seed weight is controlled by genes that have a predominance of additive effects and, even though some dominance effect may also occur, it means that cowpea seed size can be improved by selection. Teófilo et al. (1984) found a null value for the number of pairs of dominant genes that control the 100-seed weight in cowpea. This could have occurred because of the absence of main genes, or the genes cancelled out mutually because they had different signs.

There were five genes involved in the inheritance of the character studied. Bhowal (1976) found four pairs of genes and Aryeetey \& Laing (1973) found ten pairs. Sène (1968) estimated as six the number of pairs of genes concentrated in the large-seed parental, and that each gene contributed to a $1.1 \mathrm{~g}$ increase in the 100 -grain weight. Even though the expression utilized for obtaining an estimate of the number of genes or genetic blocks is based on a series of assumptions, this estimate is useful as indicator of the polygenic nature of the character studied, and in determining the probability of obtaining a genotype in a segregating population.

\section{REFERENCES}

ARAÚJO, J.P.P. Melhoramento do caupi no Brasil. In: ARAÚJO, J.P.P. de; WATT, E.E. (Org.) O caupi no Brasil. Brasília: IITA; EMBRAPA, 1988. p.249-283.

ARYEETEY, A.N.; LAING, E. Inheritance of yield components and their correlation with yield in cowpea (Vigna unguiculata (L.) Walp.). Euphytica, v.22, p.386-392, 1973.

BHOWAL, J.G. Inheritance of pod length, pod breadth and seed size in a cross between cowpea and catjang bean. The Libyan Journal of Sciences, v.6A, p.17-21, 1976.

BIRADAR, B.D.; GOUD, J.V.; PATIL, S.S. Components of variance, heritability and genetic gain in cowpea (Vigna unguiculata (L.) Walp.). Annals of Agricultural Research, v.14, p.434-437, 1993.

BIRADAR, B.D; GOUD, J.V.; PATIL, S.S. Genetic studies on seed size, protein content and grain yield of cowpea. Crop Research Hisar, v.7, p.263-268, 1994. /CD-Rom/

BORDIA, P.C.; YADAVENDRA, J.P.; KUMAR, S. Genetic variability and correlation studies in cowpea (Vigna sinensis (L.) Savi ex Hassk). Rajasthan Journal of Agricultural Science, v.4, p.39-44, 1973.

BURTON, G.W. Quantitative inheritance in pearl millet (Pennisetum glaucum). Agronomy Journal, v.43, p.409-417, 1951.

CRUZ, C.D. Programa GENES: aplicativo computacional em genética e estatística. Viçosa: UFV, 1997. 442p.

CRUZ, C.D.; REGAZZI, A.J. Modelos biométricos aplicados ao melhoramento genético. Viçosa: UFV, 1994. 309p.

DRABO, I.; LADEINDE, T.A.O.; REDDEN, R.; SMITHSON, J.B. Inheritance of seed size and number per pod in cowpeas (Vigna unguiculata (L.) Walp.) Field Crops Research, v.11, p.335-344, 1985.

DRABO, I.; REDDEN, R.; SMITHSON, J.B.; AGGARWAL, V.D. Inheritance of seed size in cowpea (Vigna unguiculata (L.) Walp.) Euphytica, v.33, p.929-934, 1984.

EHLERS, J.D.; HALL, A.E. Cowpea (Vigna unguiculata (L.) Walp.) Field Crops Research, v.53, p.187-204, 1997.

KHERADNAM, BY M.; NIKNEJAD, M. Heritability estimates and correlations of agronomic characters in cowpea (Vigna sinensis L.) Journal of Agricultural Science, v.82, p.207-208, 1974.

LOPES, A.C. de A.; FREIRE FILHO, F.R.; SILVA, R.B.Q. da; CAMPOS, F.L.; ROCHA, M. da M. Variabilidade e correlações entre caracteres agronômicos em caupi (Vigna unguiculata). Pesquisa Agropecuária Brasileira, v.36, p.515-520, 2001.

MATHER, K.; JINKS, J.L. Introdução à genética biométrica. Ribeirão Preto: SBG, 1984. 242p.

OGUNBODEDE, B.A.; FATUNLA, T. Quantitative studies of some cowpeas [Vigna unguiculata (L.) Walp.] traits. East African Agricultural and Forestry Journal, v.50, p.89-100, 1985.

RAHMAN, M.A.; SAAD, M.S. Estimation of additive, dominance and digenic epistatic interaction effects for certain yield character in Vigna sesquipedalis Fruw. Euphytica, v.114, p.61-66, 2000.

RAMALHO, M.A.P.; SANTOS, J.B. dos; ZIMMERMANN, M.J. de O. Genética quantitativa em plantas autógamas. Goiânia: Ed.UFG, 1993. 271p.

ROCHA, M.M.; CAMPELO, J.E.G.; RIBEIRO, V.Q.; FREIRE FILHO, F.R. Estimação de parâmetros genéticos em caupi (Vigna unguiculata (L.) Walp.) de tegumento branco. In: REUNIÃO DE PESQUISA DO CCA, 4; Teresina, 1995 Anais. Gráfica da UFPI, 1995. p.123-132.

SAWANT, D.S. Gene control for yield and its atributes in cowpea. Annals of Agricultural Research, v.15, p.140-143, 1994.

SÈNE, D. Hérédité du poids de cent graines chez (Vigna unguiculata (L) Walp) (Niébé) L' Agronomie Tropicale, v.23, p.1345-1351, 1968.

SHAKARAD, M.N.; ARATHI, H.S.; GANGAPPA, E.; RAMESH, S. Gene action for yield and yield attributes in cowpea (Vigna unguiculata (L.) Walp.) Mysore Journal of Agricultural Sciences, v.29, p.289-292, 1995.

TEÓFILO, E.M.; SILVA, F.P. da; ALVES, J.F.; PAIVA, J.B.; SANTOS, J.H.R. dos Análise genética de um cruzamento dialélico em caupi. Pesquisa Agropecuária Brasileira, v.19, p.849-857, 1984.

UMAHARAN, P.; ARIYANAYAGAM, R.P.; HAQUE, S.Q. Genetic nature of some pod quality characteristics in vegetable cowpea [Vigna unguiculata (L.) Walp.] Tropical Agriculture, v.74, p.277-284, 1997.

Received November 21, 2001 